\title{
Dietary Folic Acid and The Activity of Brain Cholinergic and $\gamma$-Aminobutyric Acid (GABA) Enzymes
}

\author{
M.I. BOTEZ, JOCELYNE BACHEVALIER, and G. TUNNICLIFF
}

SUMMARY: Charles River $C D$ male rats were randomly divided into 3 groups of five each and placed on folate deficient, folate excess, and control diets respectively. Glutamate decarboxylase GAD $\gamma$-aminobutyrate aminotransferase (GABA-T), choline acetyliransferase (ChAc), and acetylcholinesterase ( $A C h E$ ) were assayed in the rat brains after 6 weeks of dietary treatment. Neither folate deficiency nor folate supplementation influenced the enzymes associated with GABA and acetylcholine metabolism.

RESUME: Cetle étude a été réalisée sur des rats mâles (Charles River $C D$ ) âgés de 21 jours et répartis en 3 groupes de 5 animaux soumis à l'un des régimes alimentaires suivants: une diète totalement carencée en acide folique, une diète contrôle contenant $2 \mu \mathrm{g} / \mathrm{g}$ d'acide folique et une diète avec surdosage en acide folique $(100 \mu \mathrm{g} / \mathrm{g})$. Les animaux furent maintenus pendant 6 semaines sous ces différentes diètes après quoi les enzymes suivantes furent analysées au niveau du cerveau: la glutamate décarboxylase (GAD), la $\gamma$ aminobutyrate aminotransférase (GABA$T)$, la choline acetyltransférase (ChAc) et l'acétylcholinestérase (AChE). Les résultats ont montré que la déficience ou la surcharge en acide folique n'influencent en aucune manière les enzymes associées au métabolisme du GABA et de l'acétylcholine.

From the Clinical Research Institute of Montreal and Hôtel-Dieu Hospital, Montreal. P.Q., Canada.

This work was supported by a grant from C.O. Monat Foundation (Hôtel-Dieu Hospital).

Reprint requests 10: Dr. M.I. Botez, 110 Pine Ave West, Montreal, Quebec H2W 1R7, Canada.
The need for an explanation of folate-responsive neuropsychiatric symptoms (Reynolds, 1976; Manzoor and Runcie, 1976; Botez et al., 1978; 1979) prompted us to develop an animal model for the study of the effects of folate on behavior and brain chemistry (Bachevalier and Botez, 1978; 1978a).

Recently we have found that the concentration of 5-hydroxyindoleacetic acid is low in cerebral spinal fluid of folate-deficient patients who exhibit neuropsychiatric symptoms that respond to folic acid (Botez et al., 1979). In the same preliminary study we reported low 5-hydroxytryptamine (5-HT) levels in the brains of rats fed either a folate-deficient diet or a diet containing excess folate. This is in agreement with previous findings (Koorevar et al., 1973) showing that the regional distribution of 5-methyltetrahydrofolate in the brain is similar to that of 5-hydroxytryptamine (5HT). In earlier studies, Davies and Watkins (1973) found evidence that folate could block the inhibitory effects of GABA by up to 80 per cent.

There is a close relationship between the influence of folic acid and thiamine on the nervous system (Thomson et al., 1972). Plaitakis and coworkers (1978) demonstrated in thiamine-deficient rats a selective impairment of the cerebellar serotonergic system.

It has been reported that rats maintained on a thiamine-deficient diet show reduced brain $\gamma$-aminobutyric (GABA) acid levels (Gubler et al., 1974). However, the activities of glutamic decarboxylase (GAD) and $\gamma$-aminobutyrate aminotransferase (GABA-T) were unaffected. Reports about the effect of thiamine deficiency on the levels of acetylcholine are conflicting (Heinrich et al., 1973;
Reynolds and Blass, 1975).

The present study was carried out to determine whether a folate-deficient diet or a diet containing excess folate in rats could influence the enzymes associated with GABA and acetylcholine metabolism. Our results suggest that they do not.

\section{Methods}

Charles River CD male rats $(60-70 \mathrm{~g})$ were randomly divided into 3 groups of five each and placed on the folate diets as shown in Table 1 . The composition of the different diets has been described (Bachevalier and Botez, 1978, 1978a).

After 6 weeks the rats were killed by a sharp blow to the back of the neck. Brains were quickly removed and homogenised in 9 vol of ice-cold water.

GAD was measured by the procedure of Wu et al. (1973). However, no exogenous pyridoxal phosphate was added to the assay system. We verified that, under our conditions, the assay was linear with time and proportional to tissue concentration. GABA-T was assayed as previously described (Ngo and Tunnicliff, 1978). ChAc was measured by the procedure of McCaman and Hunt (1965); AChE was assayed as described by McCaman et al. (1968). Blood folic acid concentrations were measured as previously described (Bachevalier and Botez, 1978; 1978a).

\section{Results and Discussion}

The folic acid diets were effective in altering the blood levels of folate (Table 1). During the 6 weeks the animals were maintained on the diets, the rats from each group gained about the same weight (almost $300 \mathrm{~g}$ ). Therefore, folic acid has no effect on rats ability to gain weight.

The activity of the brain enzymes 
TABLE 1

Folate and Enzyme Determinations.

\begin{tabular}{|c|c|c|c|c|c|c|c|}
\hline \multirow[t]{2}{*}{ DIET } & \multirow{2}{*}{$\begin{array}{c}\text { WEIGHT GAINS } \\
\begin{array}{c}\text { (gr) } \\
\times \quad \pm \text { S.E. }\end{array}\end{array}$} & \multirow{2}{*}{$\begin{array}{c}\text { SERUM FOLATE } \\
\mathrm{ng} / \mathrm{ml} \\
\times \quad \text { S.E. }\end{array}$} & \multirow{2}{*}{$\begin{array}{c}\text { RBC FOLATE } \\
\mathbf{n g} / \mathbf{m l} \\
\times \quad \text { S.E. }\end{array}$} & \multicolumn{4}{|c|}{$\begin{array}{l}\text { Determinations of brain enzymes } \\
\text { in } \mu \text { moles } / \mathrm{g} / \mathrm{hr}\end{array}$} \\
\hline & & & & GAD & GABA-T & ChAc & AChE \\
\hline $\begin{array}{l}\text { Control } \\
\text { (folate deficient }+ \\
2 \mu \mathrm{g} \text { folate per } \mathrm{g} \\
\text { diet) }\end{array}$ & $293.3 \pm 13.60$ & $92.8 \pm 5.49$ & $546.7 \pm 8.70$ & $27.0 \pm 3.2$ & $101.0 \pm 11.2$ & $0.27 \pm 0.04$ & $549.9 \pm 55.5$ \\
\hline $\begin{array}{l}\text { Folate } \\
\text { deficient }\end{array}$ & $288.6 \pm 11.18$ & $21.12 \pm 2.10$ & $245.7 \pm 27.40$ & $26.4 \pm 2.1$ & $96.6 \pm 10.5$ & $0.30 \pm 0.04$ & $560.6 \pm 61.3$ \\
\hline $\begin{array}{l}\text { Folate excess } \\
\text { (folate deficient }+ \\
100 \mu \mathrm{g} \text { folate per } \mathrm{g} \\
\text { diet) }\end{array}$ & $292.7 \pm 10.93$ & $229.4 \pm 18.17$ & $1424.7 \pm 341.59$ & $28.1 \pm 3.5$ & $95.7 \pm 13.6$ & $0.25 \pm 0.05$ & $551.8 \pm 48.4$ \\
\hline
\end{tabular}

showed no differences between the dietary groups (Table 1). This is surprising in light of our previous work in which we demonstrated that folic acid can inhibit the activity of GAD in vitro (Tunnicliff and Ngo, 1977). If the folic acid diets can alter the levels of brain folic acid, then the physiological significance of the inhibition of GAD is in doubt.

We have previously shown that folic acid deficiency and excess folate can produce alterations in brain 5-HT levels (Botez et al., 1978). In the same study, we found no evidence of changes in brain dopamine or noradrenaline metabolism. Thus, as a preliminary conclusion it seems that folic acid has an effect only on serotonergic transmitter system. Further studies will have to be carried out to establish whether or not the psychiatric symptoms that are folate responsive are related to alterations in 5-HT metabolism (Botez et al., 1979).

\section{REFERENCES}

BACHEVALIER, J. and BOTEZ, M.I. (1978). Avoidance behavior in folate-deficient rats. Tohoku J. Exp. Med., 126, 111-116.

BACHEVALIER, J. and BOTEZ, M.I. (1978a). Learning in rats after large doses of folic acid. Nutr. Rep. Int., 17, 457-462.
BOTEZ, M.I., PEYRONNARD, J.M., BACHEVALIER, J. and CHARRON, L. (1978). Polyneuropathy and folate deficiency Arch. Neurol., 35, 581-584.

BOTEZ, M.I., YOUNG, S.N., BACHEVALIER, J. and GAUTHIER, S.N. (1979). Folate deficiency and decreased brain 5-hydroxytryptamine synthesis in man and rat. Nature, 278, 182-183.

BOTEZ, M.1., BOTEZ, Th., LEVEILLE, J., BIELMANN, $P$. and CADOTTE, $M$. (1979). Neuropsychological correlates of folic acid deficiency: Facts and hypotheses. In: Folic Acid in Neurology, Psychiatry and Internal Medicine eds. M.I. Botez and E.H. Reynolds. Raven Press, New York, pp. 435461.

DAVIES, J. and WATKINS, J.C. (1973). Facilitatory and direct excitatory effects of folate and folinate on single neurons of cat cerebral cortex. Biochem. Pharmacol., 22, 1167-1168.

GUBLER, C.J., ADAMS, B.L., HAMMON, B., YUAN, E.C., GUO, S.M. and BENNION, M. (1974). Effect of thiamine deprivation and thiamine antagonists on the level of $\gamma$-aminobutyric acid and on 2-oxoglutarate metabolism in rat brain. J. Neurochem., 22 , $831-836$.

HEINRICH, C.P., STADLER, H. and WEISER, H. (1973). The effect of thiamine deficiency on the acetylcoenzyme $A$ and acetylcholine levels in the rat brain. J. Neurochem., 21, 1273-1281.

KOOREVAR, W.C., GREYER, M.A., KNAPP, S., HSU, L.L. and MANDELL, A.J. (1973). Regional distribution of 5-methyltetrahydrofolic acid in brain. Nature, 245, 244-245.

LABORIT, H. (1979). The role of folic acid in central nervous system physiology. In: Folic acid in Neurology, Psychiatry and Internal Medicine eds. M.I. Botez and E.H. Reynolds. Raven Press, New York, in press.

MANZOOR, M. and RUNCIE, J. (1976). Folate-responsive neuropathy: report of 10 cases. Br. Med. J., i: 1176-1178.

McCAMAN, R.E. and HUNT, J.M. (1965). Microdetermination of choline acetylase in nervous tissue. J. Neurochem., 12, 253-259.

MCCAMAN, M.W., TOMEY, L.R. and McCAMAN, R.E. (1968). Radiometric assay of acetylcholinesterase activity in submicrogram amounts of tissue. Life Sciences, 1, 233-244.

NGO, T.T. and TUNNICLIFF, G. (1978). Further evidence for the existence of isozymes of brain $\alpha$-aminobutyrate aminotransferase. Comp. Biochem. Physiol., 59c, 101-104.

PLAITAKIS, A., NICKLAS, W.J. and BERL, S. (1978). Thiamine deficiency: Selective impairment of the cerebellar serotonergic system. Neurology, 28, 691-698.

REYNOLDS, S.F. and BLASS, J.P. (1975). Normal leyels of acetylcoenzyme $A$ and acetylcholine in the brains of thiamindeficient rats. J. Neurochem., 24, 185-186.

REYNOLDS, E.H. (1976). Neurological aspects of folate and vitamin $B_{12}$ metabolism. Clin. Haematol., 5, 661-697.

THOMSON, A.D., FRANK, O., DeANGELIS, B. and BAKER, H. (1972). Thiamine depletion induced by dietary folate deficiency in rats. Nutr. Rep. Int., 6, 107-110.

TUNICLIFF, G. and NGO, T.T. (1977). Folic acid and the inhibition of brain L-glutamic decarboxylase. Experientia, 33, 67. 